\section{HPCSA disciplinary action - 'custodian of professional morals?'}

To the Editor: In response to striking doctors, the HPCSA argues that it can investigate unprofessional conduct in the absence of a complaint because it is the custodian of professional morals. ${ }^{1}$

The HPCSA did not always hold this position; for example, when the Truth and Reconciliation Commission (TRC) made public the evidence of potential involvement of health professionals in human rights violations during apartheid, ${ }^{2}$ the HPCSA indicated it could not initiate action against named health professionals until a complaint was received. Because of this reluctance to take proactive action, 27 doctors lodged a formal complaint with the HPCSA in 2000 about the involvement of Dr Wouter Basson as head of the Chemical and Biological Warfare Programme of the South African Defence Force during apartheid. Information on over 40 doctors named at TRC hearings as having potentially been involved in human rights abuses was also provided to the HPCSA for further action. The HPCSA has acted only against Dr Basson ${ }^{3}$ and has not reached a conclusion, some 13 years after his alleged involvement in serious abuses was revealed. $^{4}$

In this light, the HPCSA's pursuit of disciplinary action against 256 doctors alleged to have been involved in strikes in KwaZuluNatal, despite the purported withdrawal of the complaints by the KZN Health Department, ${ }^{1}$ is of concern. The basis of the unethical conduct charges are unclear. None of the 16 ethical guidelines issued by the HPCSA cites strike action as unethical conduct. The ethical arguments relating to health professionals' participation in strikes are complex. ${ }^{5,6}$ While it may currently be illegal for health workers to strike, the law and ethical standards are not the same thing and have diverged substantially in the past in South Africa. ${ }^{7}$ Should the law change, what is illegal now may be legal in future, exposing the fallacy of basing ethical assessments on prevailing legislation.

Legal strikes by health workers are permitted in other countries. What makes South Africa different so as to declare striking by a health professional as unethical? The difference is largely a joint commitment by labour (health professionals) and employers (the Department of Health (DOH)) to maintain minimum essential services during a strike, reflecting a regularisation of labour action to protect patients from harm.

The DOH has agreed to the development of such a minimum service agreement. The agreement is still pending, but striking by health professionals will not be illegal if and when it is finalised. Disciplining doctors on the basis of striking being unethical fails to identify neither what in their action or inaction is unprofessional, nor that labour action in the context of protection of patient rights could be compatible with professional standards. Debates on ethical issues in strikes by health workers ${ }^{8}$ were hosted by the Wits Bioethics Centre in 2010. ${ }^{9}$ While opinions differed, all speakers agreed that the litmus test for ethical standards must be the prevention of harm to patients.

Arbitrary application of disciplinary action is clearly unconstitutional. The former South African Medical and Dental Council (SAMDC) acted against Dr Aubrey Mokoena in the absence of any complaint but on the basis of his conviction under the Terrorism Act for his political activities. ${ }^{10}$ This abuse of the SAMDC for political motives was the hallmark of the co-option of professional bodies by the apartheid government. ${ }^{2,10,11}$ We should guard against systems of professional accountability being used in a democratic South Africa for the settling of political scores. Doctors whose conduct harms patients or puts patients at risk of harm should be disciplined. However, discipline should be based on evidence of the unethical action, and aim to promote professional ethical standards and the rights of all in South Africa. Why is the vigour of the HPCSA in pursuing action against striking doctors protesting working conditions in the new South Africa not evident in response to evidence cited by the TRC of doctors potentially associated with human rights abuses during apartheid?

\section{London}

Health and Human Rights Programme

School of Public Health and Family Medicine

University of Cape Town

leslie.london@uct.ac.za

1. Bateman C. No deals for unlucky few strikers - HPCSA. S Afr Med J 2010;100:484-486.

2. Baldwin-Ragavan L, London L, de Gruchy $\mathrm{I}$. Learning from our apartheid past: Human rights challenges for health professionals in contemporary South Africa. Ethnicity and Health 2000;5(3):227-241.

3. Venter Z. 'Dr Death' to face disciplinary action. Pretoria News. 11 May 2010. http://www.iol.co.za/index. php?click_id=13\&set_id=1\&art_id=vn2010051 1043958895 C642297 (accessed 25 August 2010).

4. Burger M, Gould C. Secrets and Lies. Wouter Basson and South Africa's Chemical and Biological Warfare Programme. Cape Town: Zebra Press, 2002.

5. Ogunbanjo GA, Knapp van Bogaert D. Doctors and strike action: Can this be morally justifiable? SA Fam Pract 2009;51:306-308.

6. Bateman C. Qualified ethics nod to doctors downing tools. S Afr Med J 2009;99:294-295

7. Gillon R. Medical ethics during a period of unrest. S Afr Med J 1986;70;843.

8. Ethics Alive 2010. Health Sciences Review. Faculty of Health Sciences April 2010. http://web.wits.ac.za/ NR/rdonlyres/ABD9395C-3197-4C31-AD7A-AB9D2BD4B5E5/0/HealthSciencesReviewApril2010. pdf (accessed 25 August 2010)

9. Stuart K. Of professionalism and health care strikes. South African Journal of Bioethics and Law 2010;3:4-8.

0. Baldwin-Ragaven L, de Gruchy J, London L. An ambulance of the wrong colour. Health professionals, human rights and ethics in South Africa. Cape Town: UCT Press, 1999.

11. Kirsch RE. Doctors and the TRC - confronting our past. S Afr Med J 1997;87:711.

\section{Accreditation of training courses in good clinical practice}

To the Editor: The Medicines Control Council of South Africa requires health care professionals and others involved in conducting clinical studies to attend a training course in good clinical practice (GCP) every 3 years. The need for standardised training and accreditation in South Africa is recognised. ${ }^{1}$ However, the way in which the accreditation of training courses is to be implemented from 2011 will result in conflicts of interest that would be best avoided.

The National Health Research Ethics Council (NHREC) has decided that the South African Clinical Research Association (SACRA) should serve as the oversight body for the accreditation of GCP courses that relate to GCP training in South Africa. SACRA will organise a committee of stakeholders to give input into the process. SACRA is a non-profit and capable organisation, but is strongly linked to the pharmaceutical industry (pharma) and commercial research organisations (http://www.sacraza.com).

There are many stakeholders in research, each with specificinterestsgovernments, institutions, commercial sponsors, participants and others. These interests may conflict with each other. ${ }^{2,3}$ It is arguably unethical to single out any one player to have the predominant role, whether it be industry, government or any single university.

Pharma can take pride in its many achievements to improve health care. Pharma validly promotes clinical research for scientific and commercial reasons. The latter may, however, result in a conflict of interests, if pharma were to have a predominant influence in accrediting the training courses for such research. Notwithstanding the intention to meet high ethical standards, there are many examples in clinical research and elsewhere of misjudgements and mishaps that have arisen through neglect of avoidable conflicts of interest.

Potential unwanted and unintended consequences include bias in the accreditation of lecturers linked to industry or of lecturers who 